\title{
PERSPEKTIF BARU PENGAJARAN BAHASA INGGRIS MELALUI DIRECT METHOD: Sebuah Kajian Kritis
}

\author{
Alek \\ Fakultas Tarbiyah dan Keguruan UIN Syarif Hidayatullah \\ Jalan Ir. H. Juanda No. 95 Ciputat, Tangerang Selatan Banten \\ Email: alek_uinjkt@yahoo.com
}

\begin{abstract}
Abstrak:
Pendidik (dosen dan guru) harus kreatif dalam memilih dan menentukan metode atau pendekatan yang sesuai untuk diterapkan dalam pembelajaran. Pemilihan metode, pendekatan, model, atau strategi harus dilakukan sebelum hadir dalam ruang kelas. Pemilihan metode harus sejalan dengan tujuan pembelajaran. Analisis teoretik ini mencoba mengungkap perspektif baru penggunaan metode langsung dalam pelaksanaan pembelajaran bahasa Inggris. Menginterpretasi dan memanipulasi metode secara tepat bukan hanya meningkatkan kualitas pembelajaran melainkan juga prestasi belajar peserta didik. Menggunakan metode langsung dalam pembelajaran bahsa Inggris khususnya dalam mengajarkan keterampilan bahasa seperti, aspek tata bahasa dan berbicara secara lisan dan bahkan dalam bahasa tulis. Penerapan metode langsung dalam proses pembelajaran seharusnya memerhatikan karakteristik peserta didik dan bahan ajar yang hendak diberikan. Penggunaan metode langsung seharusnya digunakan secara terus-menerus dalam pembelajaran bahasa Inggris sebagai bahasa asing atau target.
\end{abstract}

\begin{abstract}
Lecturers and teachers should be creative in choosing and determining an appropriate method or approach to be applied in their teaching and learning. The activity of choosing and determining any technique, method, approach, model, and strategy is such a main activity before coming to the class. The fallacy of choosing method in teaching can be a paradoct to the instructional objectives. This theoretical anlaysis try to reunlock any new perspective of using direct method in conducting English teaching and learning process. The way of interpretation and manipulation of method appropriately not only can enhance the quality of teaching and learning process but also leaning outcome or students' achievement. Using direct method in teaching English, especially for teaching language skills, such as speaking, grammar aspect, not only in spoken aspect but also written one. Applying direct method in teaching and learning English should pay attention to the students and the characteristics of the materials that will be taught. The using of direct method should be continuously used in teaching and learning English as a foreign language or target language.
\end{abstract}

Kata Kunci:

Direct method, linguistik terapan, proses pembelajaran

SETIAP metode pengajaran memiliki kelebihan dan kelemahan masing-masing. Suatu metode dikatakan memiliki nilai lebih dan bermakna, manakala cocok dan dapat diterima oleh mayoritas rombongan belajar atau kelas. Akan tetapi, hal ini tidak hanya sampai ke taraf cocok atau dapat diterima itu saja, melainkan harus efektif, yakni 
melalui metode tersebut, tujuan pembelajaran dan pengajaran yang telah direncanakan dapat tercapai secara optimal. Hal tersebut seiring dengan pandangan Suherman dan Winataputra bahwa proses atau tujuan yang telah ditetapkan dapat tercapai. ${ }^{1}$

Sebuah metode pengajaran dapat memberikan hasil yang optimal, jika pengaplikasiannya mempertimbangkan berbagai faktor, di antaranya ialah peserta/mahasiswa/siswa, metode pembelajaran, bahan ajar, dan tingkat kesulitan bahan ajar yang digunakan. Bahasa Inggris adalah salah satu mata pelajaran yang diaggap sukar oleh sebagian besar mahasiswa/siswa pada semua jenjang pendidikan. Anggapan tersebut berdampak negatif bukan hanya terhadap hasil belajar mahasiswa/siswamelainkan juga terhadap motivasi dan minat belajar mereka. Hal tersebut ditandai dengan rendahnya daya serap mahasiswa/siswa yang dapat dlihat pada sangat minimnya jumlah mahasiswa/siswa yang mampu mencapai hasil belajar sesuai standar yang disyaratkan oleh kurikulum. Pada tingkat lokal, rendahnya daya serap mahasiswa/siswa dengan mudah dapat dilihat dalam suasana belajar mengajar sehari-hari. Banyak mahasiswa/siswa yang tidak hanya kurang mampu memahami isi wacana bahasa Inggris melainkan kurangnyaminat dalam diri mahasiswa/siswa dalam mengikuti pelajaran secara wajar dan partisipatif. Artinya, sebagian mahasiswa/siswa ikut belajar bahasa Inggris bukan karena suka terhadap mata pelajaran dimaksud, melainkan karena takut di-alpa dan atau tidak diikutkan dalam ujian atau tidak mendapatkan nilai. Oleh karena itu, diperlukan adanya metode pembelajaran tertentu yang relevan dengan kondisi mahasiswa/siswa secara umum.

Salah satu metode pembelajaran yang dipandang sangat relevan adalah metode pengajaran langsung (direct method) yang biasa disebut modeldemonstrasi. Pengajaran langsung sebagaimana dikemukakan oleh Kardi dan Nur adalah metode yang berpusat pada dosen/guru. ${ }^{2}$ Berbeda halnya dengan pendekatan pembelajaran lain yang pada umumnya berpusat pada mahasiswa/siswa (student-centered approach), Metode pengajaran langsung mempunyai langkah-langkah tertentu yang aplikasinya lebih banyak diperankan oleh dosen/guru daripada mahasiswa/siswa.

Berdasarkan kondisi tersebut di atas, maka penulis mencoba mebahas secara lebih fokus tentang metode pengajaran langsung dalam karya ilmiah ini sebagai sebuah alternatif dalam memahami isi wacana inggris dengan baik". Berdasarkan uraian-uraian pada latar belakang di atas, Apakah metode pengajaran langsung (direct model) dapat menjadi sebuah alternatif baru dalam pengajaran bahasa Inggris?" Tulisan ini ingin mengkaji secara teoretis tentang perspektif baru pengajaran bahasa Inggris melalui metode pengajaran langsung (direct method).

\section{Konsep Dasar Pengajaran Langsung (Direct Method)}

Pengajaran langsung pada dasarnya adalah satu metode pengajaran yang menuntut peran dosen/guru jauh lebih banyak dan bervariasi daripada mahasiswa/siswa. Istilah peran dosen/guru yang jauh lebih banyak tidak mengacu kepada kondisi di mana mahasiswa/siswa hanya bersikap pasif saja dalam menerima pelajaran. Pengajaran langsung sebagaimana dikemukakan oleh Nur adalah metode pengajaran yang menghendaki dosen/guru memberikan informasi latar belakang, mendemons- 
trasikan keterampilan yang sedang diajarkan, dan kemudian menyediakan waktu bagi mahasiswa/siswa untuk latihan keterampilan tersebut dan menerima umpan balik tentang bagaimana esensi kegiatan yang mereka sedang lakukan. Penyediaan waktu untuk latihan keterampilan itulah yang menghindarkan mahasiswa/siswa dari suasana belajar yang tidak pertisipatif kendatipun dosen/guru lebih berperan. ${ }^{3}$

Mencermati konsep tentang metode langsung dalam pengajaran bahasa bahawa peran dosen/guru seperti dimaksud di atas merupakan pemberian model atau contoh kepada mahasiswa/siswa tentang bagaimana melakukan sesuatu, sedangkan pemberian waktu untuk latihan keterampilan merupakan kegiatan yang aplikatif. Artinya, mahasiswa/siswa tidak hanya dituntut mengetahui tetapi juga mampu mengaplikasikan pengetahuan itu ke dalam bentuk tindakan nyata (real context). Model adalah pemberian contoh nyata oleh dosen/guru atau alat lain yang bisa ditiru oleh mahasiswa/siswa. ${ }^{4}$ Menurut Mas'ud pengaplikasian pengetahuan ke dalam bentuk tindakan nyata adalah salah satu cara pemecahan masalah pembelajaran yang sangat bermakna dalam kehidupan peserta didik. ${ }^{5}$ Ditinjau dari sudut historis, sekitar abad kedua puluh, berkembang pemikiran di kalangan para pemerhati dalam bidang pendidikan, terutama berkaitan dengan pembelajaran bahasa, berpendapat bahwa para pelajar, tidak lagi mengalami kesulitan dalam hal menguasai suatu bahasa, di antara metode atau cara yang dapat ditempuh ialah melalui menyimak, belajar berbicara, atau meniru ucapan dan menghubungkan suatu ungkapan dengan konteks yang dihadapinya. Dari para pencetus pemikiran ini menyimpulkan bahwa metode langusng (direct method) mirip seperti metode ketika para pelajar sedang mempelajari bahasa ibunya, dan juga mirip dengan metode mempelajari bahasa kedua (bahasa asing) tanpa banyak kesulitan, ketika mereka berpindah ke lingkungan berbahasa asing tersebut. Usaha pengumpulan dan pengembangan dari metode-metode lingual dan metode-metode alamiah (natural), telah menciptakan suatu metode baru yang disebut Metode Langsung (direct method), yang mendasarkan pada upaya mengasosiasikan kosa kata dan kalimat bahasa asing dengan berbagai benda dan kejadiannya langsung, tanpa menggunakan bahasa ibu (hanya menggunakan bahasa target). ${ }^{6}$ Sementara itu, Tarigan mengatakan bahwa prinsip Metode langsung ini sama dengan proses belajar bahasa lisan. ${ }^{7}$

\section{Ciri-ciri Metode Langsung}

Seperti halnya dengan metode-metode pengajaran yang lainnya, metode pengajaran ini memiliki ciri dan karaktersitik tersendiri. Selengkapnya mengenai ciri-ciri yang dimaksud akan diberikan sebagai berikut:

1. Materi kuliah/pelajaran pertama-tama diberikan kata demi kata, kemudian struktur kalimat.

2. Gramatika diajarkan hanya bersifat terpadu (integrated) bersamaan, dan mahasiswa/siswa tidak dituntut menghafal rumus-rumus gramatika, tetapi yang utama adalah mahasiswa/siswa mampu mengucapkan dan memahami bahasa yang diajarkan dengan baik. 
3. Dalam proses pengajaran, senantiasa menggunakan alat bantu (alat peraga) baik berupa alat peraga langsung, tidak langsung (benda tiruan) maupun peragaan melalui simbol-simbol atau gerakan-gerakan tertentu.

4. Setelah masuk kelas, mahasiswa/siswa atau peserta didik benar-benar dikondisikan untuk menerima dan bercakap-cakap dalam bahasa asing, dan dilarang menggunakan bahasa lain.

\section{Langkah-langkah Pengajaran Langsung}

Pada metode pengajaran langsung seperti diuraikan oleh Kardi terdapat 5 tahapan yang sangat penting yakni (1) menyampaikan tujuan dan mempersiapkan mahasiswa/siswa, (2) mendemonstrasikan pengetahuan atau keterampilan, (3) membimbing pelatihan, (4) mengecek pemamahaman dan memberikan umpan balik, dan (5) memberikan kesempatan untuk pelatihan lanjutan dan penerapan. ${ }^{8}$

Pada setiap tahap dari kelima tahapan tersebut, dosen/guru memainkan peranan yang sangat penting guna berlangsungnya proses pembelajaran secara efektif. Pembelajaran yang efektif seperti dikemukakan oleh Suherman adalah tercapainya tujuan pembelajaran sesuai dengan rencana yang telah ditetapkan. Pada tahap memberikan informasi tentang latar belakang bahan ajar, pentingnya pelajaran, serta mempersiapkan mahasiswa/ siswa untuk belajar. ${ }^{9}$

\section{Pelaksanaan Pengajaran Langsung}

Dalam pelaksanaan pengajaran langsung, tahapan atau langkah-langkah seperti yang telah diuraikan hendaknya selalu menjadi pedoman setiap kegiatan. Hal tersebut dimaksudkan agar sistematika pembelajaran dapat berjalan sesuai program yang telah disusun.

\section{Menjelaskan Tujuan dan Mengondisikan Mahasiswa/siswa}

Para mahasiswa/siswa perlu mengetahui dengan jelas alasan-alasan mengapa perlu berpartisipasi dalam suatu pelajaran tertentu. Mereka juga perlu mengetahui apa yang harus mereka dapat lakukan setelah ikut serta dalam pembelajaran dimaksud. Cara penyampaian tujuan pembelajaran tergantung atas kondisi mahasiswa/siswa, tetapi menuliskan di papan tulis setelah tujuan dirangkum awal, misalnya peran dosen/guru adalah menjelaskan tujuan pembelajaran, sedemikian rupa akan sangat efektif, terutama jika tujuan-tujuan tersebut diprojeksikan melalui OHP. Dengan demikian, dosen/guru dapat menghemat waktu beberapa menit sehingga efektivitas pembelajaran semakin optimal.

Kegiatan menyiapkan mahasiswa/siswa dimaksudkan untuk menarik perhatian mereka, memusatkan perhatian pada pokok pembicaraan, dan mengingatkan kembali hasil belajar yang telah dimilikinya yang relevan dengan pokok pembicaraan yang akan dipelajarinya. Tujuan tesebut seperti dikemukakan oleh Kardi dapat dicapai dengan jalan mengulang-ulang pokok-pokok pembicaraan pelajaran yang lalu ataupun dengan memberikan sejumlah pertanyaan serta latihan-latihan yang sesuai dengan materi yang telah diberikan. ${ }^{10}$ Dengan demikian, diharapkan mahasiswa/siswa mampu memahami konsep yang diajarkan dengan baik. 
Menyiapkan mahasiswa/siswa pada awal pembelajaran merupakan kegiatan yang amat penting, sebab pada saat mahasiswa/siswa masuk ke dalam kelas dan dosen/guru mengawali pembelajaran, berbagai macam pikiran terbawa ke dalam kelas. Pikiran-pikiran itu sedapat mungkin dihilangkan dari benak mahasiswa/siswa sehingga mereka dapat berkonsentrasi kepada pelajaran yang akan dihadapinya.

\section{Presentasi dan Demonstrasi}

Kunci utama keberhasilan pengajaran langsung adalah dengan menyajikan informasi sejelas mungkin dan mengikuti langkah-langkah demonstrasi yang efektif. Kejelasan penyajian informasi dapat dicapai melalui perencanaan dan pengorganisasian yang baik seperti berikut ini:

a. Kejelasan tujuan dan poin-poin utama

- Nyatakan Tujuan pembelajaran pada presentasi

- Fokuskan pada satu ide pada satu waktu tertentu

- Hindari penyimpangan dari pokok pembicaraan

b. Presentasi selangkah demi selangkah

- Presentasikan bahan dalam langkah-langkah kecil

- Organisasikan dan presentasikan bahan sedemikian rupa sehingga satu poin dikuasai sebelum poin berikutnya disajikan,

- Berikan arahan selangkah demi selangkah,

- Presentasikan suatu kerangka jika bahannya cukup kompleks

c. Prosedur spesifik dan konkret

- Berikan contoh keterampilan atau proses jika sesuai,

- Berikan penjelasan rinci dan berulang-ulang untuk poin-poin yang sulit,

- Berikan contoh-contoh konkret dan beragam,

d. Pengecekan untuk pemahaman mahasiswa/siswa

- Pastikan bahwa mahasiswa/siswa memahami satu poin sebelum melangkah ke poin berikutnya.

- Ajukan pertanyaan kepada mahasiswa/siswa untuk memonitor pemahaman mereka,

- Mintalah mahasiswa/siswa mengihtisarkan poin-poin utama dengan bahasa mereka sendiri.

- Ajarkan ulang bagian-bagian yang dirasakan sulit oleh mahasiswa/siswa. ${ }^{11}$

Pelaksanaan demonstrasi atau pemodelan didasarkan pada asumsi bahwa sebagian besar yang dipelajari berasal dari mengamati cara yang dilakukan orang lain. Tidak peduli apakah cara tersebut baik atau buruk. Jika pemodelan atau peniruan itu bagus maka hasil belajar mahasiswa/siswa pada akhirnya akan bagus pula. Sebaliknya, jika model yang ditiru itu kurang bagus, maka hasil peniruannyapun akan kurang bagus. Hal ini menunjukkan bahwa dosen/guru harus menjadi model yang baik atau menggunakan alat pemodelan yang baik sehingga proses peniruan dan hasil peniruan tersebut akhirnya berdaya guna. 


\section{Menyediakan Waktu untuk Latihan Terbimbing}

Latihan terbimbing harus diupayakan agar berjalan secara efektif dengan melibatkan mahasiswa/siswa secara aktif dalam proses pembelajaran. Untuk tujuan tersebut, prinsip-prinsip yang dikemuakan oleh Kardi dan Nur perlu dipertimbangkan, yakni: (a) tugasi mahasiswa/siswa melakukan latihan singkat dan bermakna, (b) berikan pelatihan sampai mahasiswa/siswa benar-benar menguasai konsep/keterampilan yang dipelajari, (c) hati-hati terhadap kelemahan dan kelebihan latihan berkelanjutan dan latihan terdistribusi, (d) perhatikan tahap-tahap awal pelatihan. ${ }^{12}$

\section{Mengecek Pemahaman dan Memberikan Umpan Balik}

Istilah lain untuk kegiatan ini adalah resitasi yang ditandai dengan pertanyaanpertanyaan yang dilontarkan oleh dosen/guru kepada mahasiswa/siswa. Kegiatan ini sangat urgen dalam konteks pengajaran langsung karena tanpa mengetahui kemampuan atau pemahaman mahasiswa/siswa, latihan tidak akan memberikan manfaat yang berarti. Kardi dan Nur mengemukakan bahwa pemberian umpan balik bermakna dan pengetahuan tentang hasil latihan yang telah dilakukan merupakan metode pengajaran langsung yang sangat penting. ${ }^{13}$ Umpan balik dapat dilakukan melalui berbagai cara baik lisan, tes, ataupun komentar tertulis. Berikut ini adalah langkah-langkah yang dapat dipertimbangkan untuk melakukan umpan balik yang tepat (a) berikan umpan balik sesegera mungkin setelah latihan, (b) upayakan agar umpanbalik jelas dan spesifik, (c) konsentrasi pada tingkah laku, bukan pada maksud, (d) jaga umpan balik sesuai dengan tingkat perkembangan mahasiswa/ siswa, (e) berikan pujian dan umpan-balik pada kinerja yang benar, (f) apabila memberikan umpan balik yang negatif, tunjukkan bagaimana melakukannya dengan benar, (g) bantulah mahasiswa/siswa memusatkan perhatiannya pada proses dan bukan hasil, (h) ajari mahasiswa/siswa cara memberi umpan-balik kepada dirinya sendiri, dan bagaimana menilai keberhasilan kinerjanya sendiri.

\section{Memberikan Kesempatan Latihan Mandiri}

Kegiatan ini merupakan tahap akhir dalam pengajaran langsung yang biasanya diberikan dalam bentuk pekerjaan rumah (home assigment/PR). PR dapat berhasil manakala diorganisasikan dengan baik dan benar. Salah satu pedoman yang dapat dipertimbangkan adalah seperti yang disarankan oleh Kardi dan Nur sebagai berikut: (a) tugas rumah yang diberikan bukan merupakan kelanjutan dari proses pembelajaran di kelas, tetapi kelanjutan pelatihan atau persiapan untuk pembelajaran berikutnya, (b) sebaiknya dosen/guru menginformasikan kepada orang tua mahasiswa/siswa tentang tingkat keberhasilan yang diharapkan dari mahasiswa/siswa, (c) sebaiknya dosen/guru memberikan umpan balik tentang PR tersebut. ${ }^{14}$

\section{a. Kaidah-kaidah Pengajaran Langsung}

Metode pengajaran langsung menuntut adanya kaidah-kaidah tertentu yang dapat mengatur proses berlangsungnya pembelajaran dengan baik. Kaidah-kaidah dimaksud terutama untuk mengatur bagaimana mahasiswa/siswa berbicara, prose- 
dur untuk menjamin tempo pembelajaran yang baik, strategi-strategi khusus untuk mengatur giliran keterlibatan mahasiswa/siswa, dan untuk mengatur tingkah laku mahasiswa/siswa yang menyimpang.

\section{b. Menangani mahasiswa/siswayang suka berbicara}

Seringkali ada mahasiswa/siswa yang suka berbicara tetapi bukan pada saat yang tepat sehingga dapat mengganggu berlangsungnya proses pembelajaran. Oleh karena itu, perlu penanganan yang serius berupa larangan berbicara yang diterapkan secara konsisten. Hal ini dimaksudkan untuk melatih mahasiswa/siswa agar mampu mendengarkan dan menghargai pendapat mahasiswa/siswa lain.

\section{c. Mengatur tempo pembelajaran}

Tempo pembelajaran langsung harus diatur sedemikian rupa sehingga setiap tahap dapat terlaksana sesuai program. Pengaturan tempo pembelajaran disesuaikan dengan tingkat kemampuan mahasiswa/siswa sehingga ada kemungkinan cara yang ditempuh di satu kelas berbeda dari yang dilakukan di kelas lain. Pada sekolah-sekolah tertentu yang menganut sistem kelas unggulan, pengaturan tempo pembelajaran merupakan keharusan. Sebab mahasiswa/siswa kelas unggulan mempunyai kemampuan yang rata-rata lebih tinggi daripada mahasiswa/siswa di kelas-kelas non-unggulan.

\section{d. Menangani penyimpangan tingkah laku}

Pengajaran langsung berkaitan dengan pengaturan atau pengorganisasian kelas besar. Oleh karena itu, sangat mungkin ada mahasiswa/siswa yang tidak saja pasif dalam proses belajar, tetapi juga melakukan hal-hal yang sama sekali tidak berhubungan dengan pembelajaran. Keadaan itu harus ditangani secermat dan sesegera mungkin sehingga tidak mengganggu mahasiswa/siswa lain. Kardi mengemukakan formula yang dapat dipertimbangkan untuk menangani tingkah laku mahasiswa/siswa yang menyimpang selama berlangsungnya proses pembelajaran, yakni (1) being with it, (2) overlappingness, (3) perilaku yang harus dihentikan. ${ }^{15}$

Being with it mengandung makna bahwa dosen/guru harus mampu mengenali adanya penyimpangan tingkah laku walaupun tidak melihatnya secara langsung. Mahasiswa/siswa yang menyimpangpun harus dapat dikenali dengan baik melalui keterampilan khusus yang dapat diperoleh melalui pengalaman. Dosen/guru dituntut agar memperhatikan dengan seksama mahasiswa/siswa yang mempunyai kecenderungan mengganggu ketertiban kelas terutama pada saat pelajaran berlangsung. Bila memungkinkan mahasiswa/siswa seperti itu diberikan teguran langsung yang sesuai dengan kadar penyimpangan yang dilakukannya.

Overlappingness berarti kemampuan dosen/guru untuk melakukan lebih dari satu kegiatan kelas dalam waktu yang bersamaan. Artinya, penyimpangan tingkah laku mahasiswa/siswa tetap dapat diselesaikan tanpa harus mengganggu jalannya proses pembelajaran.

Perilaku yang harus dihentikan berorientasi kepada sikap mahasiswa/siswa tertentu yang kadarnya sudah di ambang batas toleransi dalam konteks pembelajaran. Sikap seperti itu biasanya bukan hanya mengganggu satu atau dua orang mahasis- 
wa/siswa saja, melainkan semua mahasiswa/siswa dalam satu kelas, misalnya memukul-mukul meja sehingga mengakibatkan keributan.

\section{Pengajaran Langsung dalam Bahasa Inggris}

Ciri utama metode pengajaran langsung (direct method) dalam bahasa Inggris adalah peniadaan penggunaan bahasa Indonesia atau bahasa ibu pelajar untuk memahami arti kata, frasa, ataupun kalimat yang disampaikan. Semua makna kata, frasa, ataupun kalimat yang ingin diajarkan kepada mahasiswa/siswa disampaikan melalui tindakan, gerakan anggota badan, menunjuk benda-benda nyata secara langsung atau menggunakan realia, serta menjelaskannya secara kontekstual. Menurut Richards dan Rodgers implementasi metode langsung (direct method) yang dahulu bernama "traditional method" adalah menggunakan bahasa sasaran dalam suasana komunikatif tanpa diselingi oleh bahasa ibu pelajar dengan mengabaikan aturan-aturan atau tatabahasa (grammar)dari bahasa sasaran tersebut. ${ }^{16}$

Menurut teori kebahasaan, perspektif baru pengimplementasian metode pengajaran langsung relevan dengan konsep bahwa fungsi utama bahasa adalah sebagai alat komunikasi. Oleh karena itu, harus diajarkan dalam konteks komunikatif dengan menggunakan bahasa tersebut secara langsung. Aturan-aturan gramatikal bahasa tersebut boleh diabaikan karena yang terpenting adalah terjadinya saling pengertian dalam konteks komunikasi.

Dalam hal pembelajaran, metode langsung ini berasumsi bahwa seseorang dapat menguasai suatu bahasa melalui penjelasan langsung dengan menggunakan bahasa sasaran (language target). Artinya penjelasan terhadap hal-hal yang kurang atau tidak dimengerti oleh mahasiswa/siswa dilakukan dengan menggunakan bahasa Inggris yang dijabarkan ke dalam teknik-teknik sebagai berikut:

- Exemplification

- Explanation

- Extension

- Repetition

- Contextualization

Metode pengajaran untuk sebuah wacana dengan menerapkan pendekatan langsung dilakukan melalui tahapantahapan sebagai berikut:

- Pre-reading

- Whilst-reading

- Post-reading

Pre-reading adalah kegiatan pembelajaran yang berupa pemberian informasi kepada mahasiswa/siswa tentang kandungan wacana yang akan disajikan secara tidak langsung dan bersifat warming up. Warming up dilakukan dengan mengajukan pertanyaan-pertanyaan ringan yang berhubungan dengan isi wacana tetapi bukan isi wacana itu sendiri.

Whilst-reading adalah kegiatan utama yang dilakukan dalam bentuk pemberian tugas-tugas pembelajaran tentang isi wacana. Biasanya dimulai dari tugas yang pa- 
ling ringan dan secara bertahap sesuai dengan tingkat pemahaman mahasiswa/siswa diarahkan menuju tugas-tugas yang lebuh berat. Tugas pertama pada umumnya dikerjakan oleh mahasiswa/siswa secara perorangan tetapi untuk tugas (tasks) berikutnya dilakukan secara berkelompok karena tingkat kesulitan pertanyaan yang juga semakin meningkat.

Jawaban atas pertanyaan-pertanyaan dalam kegiatan ini diberikan dengan menyuruh mahasiswa/siswa secara bergiliran mengucapkannya atau menuliskannya di papan tulis sesuai dengan jawaban yang mereka temukan. Dalam konteks ini, sering terjadi 3-5 jawaban yang berbeda bahkan kadangkadang lebih, namun tidak ada satupun yang tepat sesuai pertanyaan dan isi wacana. Dalam kondisi seperti ini, dosen/guru harus mengambil inisiatif membantu mahasiswa/siswa dengan memberikan tanda khusus (clue) sehingga jawaban yang tepat lebih muda ditemukan.

Alokasi waktu untuk kegiatan whislt-reading jauh lebih banyak daripada prereading dan post-reading yang masing-masing hanya berkisar antara 3-7 menit dari total waktu pengajaran wacana yang biasanya berlamgsung selama $2 \times 45$ menit. Walaupun demikian, seringkali terjadi waktu sudah habis tetapi tugas-tugas (tasks) yang harus diselesaikan belum terlaksana. Untuk hal seperti itu, tugas (task) yang tersisa dipindahkan ke kegiatan post-reading yang biasanya dikemas dalam bentuk tugas dikerjakan di rumah (home assignment atau homework).

Kegiatan post-reading adalah penguatan terhadap task-task yang dilakukan pada kegiatan whislt reading sehingga acapkali berwujud PR seperti disebutkan di atas Akan tetapi pemberian PR tidak selamanya harus dilakukan melainkan tergantung pada kebutuhan mahasiswa/siswa terutama jika ada task yang terlangkahi pada kegiatan whislt reading. Selain itu, post reading juga berisi kegiatan resume yang dilakukan secara bersama-sama oleh dosen/guru dan mahasiswa/siswa.

Pengajaran grammar atau structure yang biasa diistilahkan language focus dalam buku-buku ajar dalam Metode pengajaran langsung dilakukan melalui tahapan-tahapan sebagai berikut:

- Experience

- Generalization

- Reinforcement

- UselApplication

Keempat tahapan ini sering disingkat EGRU atau EGRA yang pelaksanaannya sama seperti dalam pengajaran wacana, yakni diupayakan menghindari penggunaan Bahasa Indonesia atau bahasa ibu pelajar atau penerjemahan ntuk menjelaskan suatu hal yang tidak dapat dipahami oleh mahasiswa/siswa. Hanya saja, seperti dikemukakan oleh Wehantouw, cara seperti itu hendaknya lebih lunak dan toleran daripada ketika mengajarkan wacana karena menyangkut aturan (rules) Bahasa Inggris. ${ }^{17}$

Kegiatan experience (E) dilakukan dalam wujud pemberian seperangkat contohcontoh kalimat yang dituliskan di papan tulis atau melalui OHP. Isi contoh-contoh kalimat tersebut adalah pola-pola language focus yang akan segera diajarkan. Satu hal yang, seyogyanya menjadi pertimbangan sehubungan dengan contoh-contoh kalimat 
dimaksud adalah kebermaknaan atau kontekstualitasnya. Artinya, kalimat-kalimat itu sedapat mungkin yang biasa didengar oleh mahasiswa/siswa dalam kehidupan sehari-hari. Dengan demikian, mereka akan merasa terbantu oleh skemata yang mereka miliki. Misalnya, ketika akan mengajarkan aturan tentang simple present maka contoh-contoh kalimat yang benar-benar yang dialamai oleh mahasiswa/siswa atau peserta didik (experience) dapat berupa:

- The sun rises in the east. The sun sets in the west.

- Alek goes to school on foot.

- We go to the party by bus.

- The boys are in the library.

- The girl is in the canteen.

Dari contoh-contoh tersebut, mahasiswa/siswa diajak memilah-milah subjek, predikat, obyek dan komplemen kalimat jika ada dengan menggunakan bahasa Inggris. Jumlah kalimat sebagai kegiatan experience hendaknya mewakili semua pola kalimat yang akan diajarkan baik kalimat verbal maupun kalimat nominal.

Kegiatan selanjutnya adalah generalization $(G)$ yakni memberikan seperangkat contoh-contoh kalimat, baik yang sesuai dengan aturan item pembelajaran yang sedang dipelajari maupun yang menyimpang. Mahasiswa/siswa diminta mengidentifikasi kalimat-kalimat yang sesuai dengan aturan, sedangkan yang menyimpang tidak digubris sama sekali. Untuk mengecek pemahaman mahasiswa/siswa, mereka diminta menyebutkan ciri-ciri baku suatu aturan yang terdapat dalam kalimat-kalimat contoh. Kegiatan mengecek ini bisa melibatkan 3-5 orang mahasiswa/siswa, yakni sampai semua ciri aturan disebutkan. Perlu dicatat bahwa penggunaan bahasa Inggris ketika menyebutkan ciri-ciri aturan tetap mendapat penekanan sehingga bentuk metode pengajaran langsung tetap terjamin.

Kegiatan reinforcement (R) masih berkisar pada pemberian contoh-contoh kalimat tentang aturan yang sedang diajarkan, hanya saja jumlahnya agak lebih banyak dan waktunyapun lebih lama. Tujuan yang ingin dicapai melalui kegiatan ini adalah peningkatan pemahaman mahasiswa/siswa tentang tata aturan yang diajarkan tersebut. Dengan demikian, kegiatan berikutnya dapat berjalan lebih lancar dan mudah.

Kegiatan use (U) atau application (A) adalah puncak aktivitas untuk mengecek pemahaman mahasiswa/siswa secara menyeluruh. Perbedaan utama dari kegiatan reinforcement adalah substansinya yang bersifat lebih komprehensif aplikatif. Sebab mahasiswa/siswa tidak diberikan kalimat-kalimat untuk diidentifikasi melainkan disuruh membuat sendiri kalimat-kalimat sesuai tata aturan yang baru saja diajarkan. Dalam konteks ini, tantangan yang dihadapi mahasiswa/siswa jauh lebih berat sebab mereka tidak saja dituntut untuk menerapkan satu aspek bahasa, tetapi tiga aspek sekaligus, yakni vocabulary, grammar atau structure dan writing.

Vocabulary, karena mereka disuruh membuat kalimat dengan menggunakan kata-kata sendiri tanpa meniru contoh-contoh yang sudah ada. Grammar atau structure, yakni menerapkan konsep yang baru diajarkan. Sedangkan writing yakni, perwujudan konsep yang baru diajarkan ke dalam bentuk tulisan baik sebagai kalimat-kalimat 
tunggal maupun wacana sederhana. Teknik pengajaran yang dapat diterapkan dalam kegiatan use atau application ini dapat berupa discovery maupun inquiry. Discovery dilakukan dengan memberikan sejumlah pola kalimat kemudian mahasiswa/siswa diminta membuat kalimat berdasarkan pola yang diberikan tersebut. Pelaksanaan teknik pengajaran inquiry yaitu kebalikan dari teknik discovery, yakni mahasiswa/siswa diberikan sejumlah kalimat lengkap kemudian mereka disuruh menemukan pola-pola kalimat dimaksud.

Kegiatan use atau application ini dapat bersifat individu, kelompok, dan dapat pula dalam bentuk Home Assignment. Penentuan apakah suatu assignment sebaiknya individu ataukah kelompok tergantung atas tingkat kesulitan tugas yang diberikan serta relevan dengan pemahaman kebanyakan mahasiswa/siswa. Dengan banyaknya kegiatan pembelajaran yang dilakukan secara langsung, maka lambat laun mahasiswa/siswa belajar seolah-olah tanpa rencana melainkan melalui proses alami dalam bentuk peniruan-peniruan. Sama seperti ketika seorang anak kecil memperoleh bahasa ibunya, yakni melalui proses mendengar kata-kata atau suara-suara dari lingkungan sekitarnya. Proses seperti itu berlangsunq secara alami tanpa banyak campur tangan dari orang lain. Seseorang akan dapat menggunakan suatu bahasa karena selalu mendengarnya walaupun tidak diberikan pengajaran khusus.

\section{PEMBAHASAN}

Berdasarkan uraian dan argumentasi teoretis yang dikemukakan di awal, pembahasan mengenai pengajaran yang menggunakan metode langsung akan diperikan sebagai berikut. Pembahasan ini diawali dengan aspek kelebihan/kebaikan dari pengajaran yang menggunakan metode langsung (direct). Direct artinya langsung. Direct method atau metode langsung yaitu suatu cara mengajikan materi pelajaran bahasa asing di mana dosen/guru langsung menggunakan bahasa asing tersebut sebagai bahasa pengantar, dan tidak menggunakan bahasa mahasiswa/siswa sedikit pun dalam mengajar. Jika ada suatu kata-kata yang sulit dimengerti oleh mahasiswa/siswa, maka dosen/guru dapat mengartikan dengan menggunakan alat peraga, mendemontstrasikan, menggambarkan dan lain-lain.

Metode langsung berpijak dari pemahaman bahwa pengajaran bahasa asing tidak sama halnya dengan mengajar ilmu pasti alam. Jika mengajar ilmu pasti, mahasiswa/siswa dituntut agar dapat menghafal rumus-rumus tertentu, berpikir, dan mengingat, maka dalam pengajaran bahasa, mahasiswa/siswa/mahasiswa/siswa dilatih praktek langsunng mengucapkan kata-kata atau kalimat-kalimat tertentu. Sekalipun kata-kata atau kalimat tersebut mula-mula masih asing dan tidak dipahami mahasiswa/siswa, namun sedikit demi sedikit kata-kata dan kalimat itu akan dapat diucapkan dan dapat pula mengartikannya.Demikian halnya kalau kita perhatikan seorang ibu mengajarkan bahasa kepada anak-anaknya langsung dengan mengajarinya, menuntunnya mengucapkan kata per kata, kalimat per kalimat dan anaknya menurutinya meskipun masih terihat lucu. Misalnya ibunya mengajar "Ayah" maka anak tersebut menyebut "Aah" dan seterusnya. Namun lama kelamaan si anak mengenali 
kata-kata itu dan akhirnya ia mengerti pula maksudnya. Pada prinsipnya metode langsung (direct method) ini sangat utama dalam mengajar bahasa asing, karena melalui metode ini mahasiswa/siswa dapat langsung melatih kemahiran lidah tanpa menggunakan bahasa ibu (mother tongue). Meskipun pada mulanya terlihat sulit untuk menuirukannya, tapi adalah menarik bagi mahasiswa/siswa.

Metode langsung (direct) dilihat dari segi efektivitasnya memiliki keunggulan antara lain: (1) mahasiswa/siswa termotivasi untuk dapat menyebutkan dan mengerti kata-kata kalimat dalam bahasa sasaran (Inggris) yang diajarkan oleh dosen/gurunya, apalagi dosen/guru menggunakan alat peraga dan macam-macam media yang menyenangkan sebagai sarana pendukung dan penjelas; (2) metode ini biasanya dosen/guru mula-mula mengajarkan kata-kata dan kalimat-kalimat sederhana yang dapat dimengerti dan diketahui oleh mahasiswa/ siswa dalam bahasa sehari-hari, misalnya (pena, pensil, bangku, meja, dan lain-lain), maka mahasiswa/siswa dapat dengan mudah menangkap simbol-simbol bahasa yang diajarkan dosen/gurunya; (3) metode ini relatif banyak menggunakan berbagai macam alat peraga: apakah video, film, radio kaset, tape recorder, dan berbagai media/alat peraga yang dibuat sendiri, maka metode ini membangkitkan minat mahasiswa/siswa. Jika mahasiswa/siswa merasa senang/tertarik, maka pelajaran atau materi yang diajarkan terasa tidak sulit; (4) mahasiswa/siswa memeroleh pengalaman langsung danpraktis, meskipun mula-mula kalimat yang diucapkan itu belum dimengerti dan dipahami sepenuhnya; (5) alat ucap/lidah mahasiswa/siswa/peserta didik menjadi terlatih dan jika menerima ucapan-ucapan yang semula sering terdengar dan terucapkan.

Sementara itu, di sisi lain, metode ini memiliki beberapa kekurangan, antara lain: (1) pengajaran dapat menjadi pasif, jika dosen/guru tidak dapat memotivasi mahasiswa/siswa/peserta didik, bahkan mungkin sekali mahasiswa/siswa merasa jenuh dan bosan karena kata-kata dan kalimat yang dituturkan dosen/gurunya sulit dimengerti, karena dosen/guru hanya menggunakan bahasa yang diajarkan (Inggris) tidak diterjemahkan ke dalam bahasa peserta didik; (2) pada tingkat-tingkat permulaan, tampaknya metode ini terasa sulit diterapkan, karena mahasiswa/siswa belum memiliki atau menguasai kosakata (perbendaharaan kata) yang masih terbatas; dan (3) meskipun pada dasarnya metode ini, dosen/guru tidak boleh menggunakan bahasa sehari-hari dalam menyampaikan bahan pelajaran bahasa asing (Inggris), akan tetapi pada kenyataannya tidak selalu demikian, dosen/guru biasanya menerjemahkan kata-kata sulit ke dalam bahasa peserta/mahasiswa/siswa. Metode ini sebenarnya tepat sekali digunakan pada semua tingkatan/level sesuai dengan ciri dan karaktersitik materi ajar yang akan disampaikan. Penggunaan metode ini pada tingkat/level lanjutan, peserta dianggap telah memiliki bahan untuk berbicara. Peserta/mahasiswa/siswa betul-betul merasa tertantang untuk berbicara/berkomunikasi dengan menggunakan bahasa sasaran. Akan tetapi, satu hal yang perlu dilupakan dalam proses penggunaan pada tingkat ini, perserta didik atau rombongan belajar diberi sanksi atau hukuman bagi mereka yang tidak mengikuti ketentuan yang telah disepakati. 


\section{SIMPULAN}

Berdasarkan uraian dan pembahasan yang dikemukakan di sebelum, penulis dapat mengemukakan beberapa simpulan:

1. Penggunaan metode pengajaran langsung, khususnya dalam mengajar bahasa Inggris dapat membangkitkan semangat rombongan belajar/peserta didik karena dalam proses belajar dan mengajar dosen/guru sedapat mungkin mengajarkan sesuatu yang bersifat kontekstual.

2. Melalui penerapan metode pengajaran langsung dapat membantu mahasiswa/siswa dalam memahami pesan-pesan, baik dalam bahasa tulis (wacana tulis/written discourse) maupun dalam bahasa lisan (wacana lisan/spoken discourse);

3. Metode pengajaran langsung dalam mengajar bahasa Inggris, terutama tentang keterampilan berbicara (speaking skill) atau pemahaman tatabahasa bahasa Inggris, baik dalam bentuk bahasa lissan maupun tulisan;

4. Metode pengajaran langsung cocok diterapkan pada mahasiswa/siswa yang memiliki karakteristik yang sama;dan

5. Metode pengajaran langsung dapat digunakan dalam mengajarkan bahasa Inggris pada semua level atau tingkatan karena dapat meningkatkan minat dan motivasi belajar mahasiswa/siswa atau peserta didik.

\section{SARAN}

Berdasarkan uraian, pembahasan, dan simpulan dikemukakan sebelum, penulis dapat menyampaikan beberapa saran kepada:

1. Dosen/guru senantiasa kreatif dan inovatif dalam memilih dan menetapkan metode, teknik, pendekatan, model, dan strategi yang tepat dalam pengajaran dan pembelajaran agar kemampuan tujuan pembelajaran tercapai.

2. Dosen/guru sebaiknya mmerhatikan karakteristik mahasiswa/siswa yang diajarnya dengan mempertimbangkan bahan ajar dan tingkat kemampuan mayoritas mahasiswa/siswa dalam satu kelas ketika menggunakan sebuah metode tertentu. Dengan demikian, efektivitas dan efisiensi proses pembelajaran dapat dioptimalkan.

\section{CATATAN AKHIR:}

1. Erman Suherman dan Udin S. Winataputra, Strategi Belajar-Mengajar Matematika, Jakarta: Departemen Pendidikan dan Kebudayaan, 1995, h. 140.

2. Suparman Kardi dan Muhammad Nur, Pengajaran Langsung, Pusat Sains dan Matematika Sekolah, Program Pascasarjana Unesa, Surabaya: University Press, 2000, h. 7.

3. Muhammad Nur, Strategi-strategi Belajar, Pusat Studi Matematika dan IPA Sekolah, Universitas Negeri Surabaya, Surabaya: University Press, 2000, h. 46.

4. Departemen Pendidikan Nasional, Pendekatan Kontekstual, Direktorat Jenderal Pendidikan Dasar dan Menengah, Direktorat Pendidikan Lanjutan Pertama, Jakarta, 2002, h. 16.

5. Abdurrahman Mas'ud, Menggagas Format Pendidikan Nondikotomik, Yogyakarta: Gama Media, 2003, h. 145. 
6. Kridalaksana, Harimurti, Kamus Linguistik, Edisi IV, Cetakan II, Jakarta: Gramedia, 2009, h. 154.

7. Henry Guntur Tarigan, Metodologi Pengajaran Bahasa 1, Edisi Revisi, Bandung: Penerbit Angkasa, 2009, h. 100.

8. Kardi, o. cit., h. 6.

9. Suherman, op.cit., h. 140.

10. Kardi dan Nur, op.cit., h. 29.

11. Ibid., h. 32.

12. Ibid., h. 35 .

13. Ibid., h. 37.

14. Ibid., h. 43.

15. Ibid., h. $48-49$.

16. Richards, Jack C. dan Theodore S. Rodgers, Approaches and Method in Language Teaching, Melbourne: Cambridge University Press, 1986, h. 128.

17. Wehantouw, The Teaching of English to Non-Native Speakers, Ujung Pandang: Hasanuddin University Press, 1995, h. 67.

\section{DAFTAR PUSTAKA}

Departemen Pendidikan Nasional. Pendekatan Kontekstual. Direktorat Jenderal Pendidikan Dasar dan Menengah. Direktorat Pendidikan Lanjutan Pertama. Jakarta, 2002.

http://id.shvoong.com/social-sciences/education/2113127-kelebihan-dan-kekuranganmetode-langsung/\#ixzz1XE4XwMm3

Ibrahim, Muslimin dan Muhammad Nur. Pengajaran Berdasarkan Masalah. Pusat Sains dan Matematika Sekolah, Program Pascasarjana Unesa, Surabaya, 2000.

Ibrahim, Muslimin dkk. Pembelajaran Kooperatif. Pusat Sains dan Matematika Sekolah. Program Pascasarjana Unesa. Surabaya, 2000.

Kardi, Suparman dan Muhammad Nur. Pengajaran Langsung. Pusat Sains dan Matematika Sekolah. Program Pascasarjana Unesa. Surabaya: University Press, 2000.

Kridalaksana, Harimurti. Kamus Linguistik. Ed. IV. Cetakan II. Jakarta: Gramedia, 2009.

Mas'ud, Abdurrahman. Menggagas Format Pendidikan Nondikotomik. Yogyakarta: Gama Media, 2003.

Nur, Muhammad. Strategi-strategi Belajar. Pusat Studi Matematika dan IPA Sekolah, Universitas Negeri Surabaya. Surabaya: University Press, 2000.

Richards, Jack C., dan Theodore S. Rodgers. Approaches and Method in Language Teaching. Melbourne: Cambridge University Press, 1986.

Arikunto, Suharsimi. Prosedur Penelitian; Suatu Pendekatan Praktis. Edisi Revisi I. Jakarta: Rineka Cipta, 1993.

Suherman, Erman dan Udin S. Winataputra. Strategi Belajar-Mengajar Matematika. Jakarta: Departemen Pendidikan dan Kebudayaan, 1995.

Tarigan, Henry Guntur. Metodologi Pengajaran Bahasa 1. Edisi Revisi. Bandung: Penerbit Angkasa, 2009.

Wehantouw. The Teaching of English to Non-Native Speakers. Ujung Pandang: Hasanuddin University Press, 1995. 